tions reporting on work carried out in the Council's laboratories (Pp, v +433. Ottawa: National Research Council of Canada, 1964). It supplements tho third edition, which covored the period 1918 52, and the 1953-58 supploment, both of which are now out of print. The list is to be kopt up to date by the publication of quorterly and annual cumulations. Part 1 contains reforenees to roprints of papers and other miscellaneous reports which form part of the National Resoarch Council numbered series, together with an author index and a computor-produced KWIC (Keyword in Context indox) which provides a subject index to the publications. Part 2 provides bibliographical information regarding the seven scientific journals published by the Research Council and the various serials and irregular publications issued by the Divisions of the Council. These publications are not included in the numbered series. Most of the publications are distributed without charge, but certain selected reports are for sale and for these the prico is quoted. 7,807 publicaicions are listed in Part 1, and each item contains the title, author and journal reference.

\section{The Physical Review}

THe Physical Review for 1965 is to be about doublo tho sizo of the 1960 volume. This represonts growth at a rate of approximately 20 per cent per annum. In 1964 the I'hysical Review divided its issues into two separate sections, $A$ and $B$, each dealing with particular branches of physics. During 1965 subscribors who are members of the American Physical Society may subscribe to either Section $A$ or $B$ in lieu of the whole journal ; the table of contents of both sections will be printed in each section. The subject index has beon extensively revised and a copy of the new list of subject entries to be used during 1965 appeared in No. $7 A B$ of the Review for December 28, 1964. This number containod also the analytical subjoct index to Volume 136 (Oct.-Dec. 1964) and a cumulative author index to Volumes 133-136 (Jan.-Dec. 1964) inclusive.

\section{The Library in the Hospital}

The papers given at the Hospital Libraries and Handicapped Readers Group Conference and Week-end School at the University of Nottingham in July 1963 have now boon published under the titlo The Library in the Hospital and Care in the Community (Pp. 32. London: Tho Library Association, 1964. 9s. L.A. mombers 6s. 9d.). There are papers by R. Sturt and Mona E. Goring which deal, respectively, with the library in the hospital and care in the community, and others by Brenda Sanders on the library and its work, by S. J. Paget on a book service for housobound raaders, and by Lorna M. Cowburn on books for blind readers. Barbara Serivens describes work in the wards and A. Shirley Wyatt the hospital and ancil. lary servicos provided by Lewisham Borough Council. Tho closo link which is developing botween hospital libraries and the care sorvices which public libraries are beginning to provide is omphasized and the potentialities are woll displayed.

\section{Durban Museum and Art Gallery}

THE annual report of the Durban Museum and Art Gallery for 1963-64 records that the new Ethnographical Hall was completed during the year and tho (toological and, Palaeontological Hall was partially completed (Pp. 23. Durban: Durban Museum, 1965). Working, display and storage facilities at the Old House Museum romain cramped. The present policy of the oommittoo is that the Old House should revert to its original purpose, showing a replica of the settler's home of the Colonial ora in Natal, while the Old Court House should be planned as a museum of Natal history. The major effort in the field was a collocting expedition to southern and western Mataboleland. A book by the Director ontitled The Birds of Natal and Zululand has boen published and other members of the staff have boen engerged on writing papers concerning their research work.

\section{Institute of Applied Science, Victoria}

THe yoar July 1963-June 1964 was an important one for the Institute of Applied Science of Victoria, and one of the chief decisions of the Trustees was the re-allocation of areas to be vacated by the National Gallory. This will require the Institute to remove almost all its displays and services to now galleries, at present arranged for art display, and thus requiring extensive modification. A halfscale model of Mariner II mado in the workshops proved a great attraction to visitors. It is some $6 \mathrm{ft}$. high and $9 \mathrm{ft}$. across its solar battery oxterisions and hangs from the high ceiling in the contre of the main gallery. Nearby hangs a half-scale model of Sputnik $I$, the first man-made. artificial earth satellite. There havo also been additions made to the sections dealing with land, air and sea transport, and an instructive new exhibit on radioactivity takes tho form of a $\gamma$-ray absorption domonstration (Report of Activities, 1963-64. Pp. 23. Melbourne: Institute of Applied Scionco of Victoria, 1964).

\section{Cosmic Rays}

THE eighth international conference on "Cosmic Rays", hold in Jaipur, India, during Decomber 2-14, 1963, was sponsored by the Cosmic Ray Commission of the International Union of Pure and Applied Physics, and the Department of Atomic Energy, Govornment of India. There were 54 sessions at which 213 contributed and 58 invited papers were presented. The Proceedings of tho conference aro being published in six volumes, dealing rospoctively with solar particles and Sun-Earth relations; modulation; composition, origin and prehistory; oxtensive air showers; high energy intoractions; and muons and neutrinos. The first volume in the series, Solar Particles and Sun-Earth Relations, has now beon published (Pp. 265. Colaba, Bombay: Tata Institute of Fundamental Research, 1964). Its contents comprise 21 articles, two dealing with the Sun, eight with solar particle detection, nine with plasma phonomena and the solar wind, and two with radiation belts. All contributions received up to February 1964 have been included. The toxt consists of standard typescript matorial reproduced by the photooffset procoss, and since some contributors did not comply with the request to ensure that their contributions were in suitably typed form for printing by photo-offset mothods several articles have had to be retypod and figures redrawn. Additional errors may thus have been introduced. The Proceedings have been edited by R. R. Daniel, P. J. Lavakare, M. G. K. Menon, S. Naranan, N. W. Nerurkar, Yash Pal and B. V. Sreokantan.

\section{Theoretical Seismology}

$\Lambda$ seminar in theoretical seismology, probably the first of its kind in India, was held in the Department of Mathematics, Kurukshetra University, during November $9-18,1964$, on the occasion of the visit of Dr. E. R. Lapwood, a noted British seismologist. The seminar was finanoed by the Univorsity Grants Commission, India. There were about twenty participants from different parts of India, including representatives of the Oil and Natural Gas Commission, Atomic Energy Commission, Meteorological Department, the Government of India, the Defence Science Laboratory and various university centros in India carrying on rosoarch in soismology, who took part in the sominar. There were twenty-four one-hour lectures followed by informal discussions. Topies coverod at the seminar included: changes in pulse shape in elastic wave propagation; radiation patterns from surface faults; modern work in seismology (six loctures by F, R. Lapwood); diffraction of sound pulses (S. K. Mishra); diffracted elastic waves (S. J. Singh); finito source problems (K. Viswanathan, V. S. Bakshi); surface dis- 